\title{
ANALISIS DAMPAK PELABUHAN (JIIPE) GRESIK TERHADAP POTENSI DESA MENGARE MENGGUNAKAN METODE SWOT-DELPHI
}

\author{
Prihono $^{1)}$, Adi Rifqi ${ }^{2)}$ \\ ${ }^{1}$ Prodi Teknik Industri, Fakultas Teknologi Industri, Universitas PGRI Adi Buana Surabaya \\ Email : prihono@unipasby.ac.id \\ ${ }^{2}$ Prodi Teknik Industri, Fakultas Teknologi Industri, Universitas PGRI Adi Buana Surabaya \\ adirifqi29@gmail.com
}

\begin{abstract}
The development of Pelindo III (JIIPE) port of Gresik Region brings opportunities for better welfare improvement for Mengare Village community. The purpose of this study is to determine the positive and negative impacts and potentials that can be managed and utilized optimally by Mengare Village community in an effort to improve the economy and welfare of the community. The method used is SWOT and Delphi method. Data collection techniques collected were interviews, observations, questionnaires, and documentation. The results of this study indicate that the development of Pelindo III (JIIPE) port has a positive impact that the community can work together with the government and the port in providing infrastructure and supporting infrastructure in managing the potential of the village, the community can open various businesses around the port area besides the parties Ports also provide opportunities for the community in recruitment of workers in accordance with the capabilities required by the port. While the negative impact of the port is to narrow the location of fishermen in fishing, the globalization of the free market so that the possibility of unhealthy competition in society and the possibility of increasing the level of unemployment in fishermen. The results of weighting the SWOT questionnaire and the Delphi priority level decision resulted in an alternative Strength-Opportunity (SO) strategy with a weighted number of 2.30, which means using the power to opportunities exist.
\end{abstract}

Keywords: Port Impact, Village Potential, SWOT, Delphi.

\section{PENDAhULUAN}

Pembangunan adalah upaya yang dilakukan oleh manusia untuk memperbaiki suatu keadaan dalam berbagai aspek kehidupan, antara lain masyarakat, ekonomi, sosial, budaya, dan politik yang berlangsung di tingkat daerah maupun tingkat nasional. Pembangunan wilayah di Indonesia perlu direncanakan atas dasar potensi geografis mencakup fisik, biotis dan sumber daya manusia serta sosio-kulturnya Worosuprodjo, (2007). Paradigma pembangunan saat ini perlu memperhatikan kekhususan wilayah yang dapat meningkatkan potensinya Daryanto, (2004). Menurut Siagian (2008), pembangunan adalah seluruh usaha yang dilakukan oleh suatu masyarakat untuk memperbaiki tata kehidupannya sebagai suatu bangsa, dalam berbagai aspek kehidupan bangsa tersebut dalam rangka pencapaian tujuan yang telah ditetapkan sebelumnya.

Menurut Goulet (dalam Sjafari dan Sumaryo, 2012). Ada tiga inti nilai-nilai yang terkandung dalam pengertian pembangunan, yaitu (1) tercapainya swasembada dalam hal kebutuhan dasar, (2) peningkatan harga diri dalam arti peningkatan percaya diri dan dimanfaatkan pihak lain untuk kepentingan mereka, (3) diperolehnya kebebasan memilih alternatif untuk mewujudkan perbaikan mutu hidup atau kesejahteraan. Hoselitz dalam Listiyaningsih membahas faktor yang dianggap penting dalam pembangunan. Menurutnya, kondisi lingkungan harus dicari terutama dalam aspek-aspek non ekonomi dari masyarakat. Alex Inkles dan David Smith (dalam Listiyaningsih, 2014) mengemukakan pendapat bahwa pembangunan bukan sekadar pemasok modal dan teknologi saja, melainkan dibutuhkan 
manusia yang dapat mengembangkan sarana material tersebut supaya menjadi produktif untuk itu dibutuhkan apa yang disebut manusia modern.

Todaro (2006) berpendapat bahwa tujuan inti pembangunan adalah peningkatan ketersediaan dan perluasan distribusi berbagai barang kehidupan pokok seperti sandang, pangan, papan, kesehatan dan perlindungan serta keamanan. Tujuan kedua adalah peningkatan standar hidup, yang tidak hanya diartikan sebagai peningkatan pendapatan, tetapi juga penyediaan lapangan pekerjaan, serta perbaikan kualitas pendidikan. Sedangkan, tujuan ketiga adalah perluasan pilihan-pilihan ekonomis dan sosial bagi setiap individu secara keseluruhan. Berdasarkan penjabaran tersebut, dapat disimpulkan bahwa tujuan inti pembangunan adalah mencapai kesejahteraan, perbaikan kondisi ekonomi, dan pertumbuhan ekonomi yang baik.

Salah satu kriteria penilaian terhadap kesejahteraan suatu masyarakat terkait dengan adanya pembangunan pelabuhan adalah adanya kegiatan pelabuhan yang beroperasi di suatu wilayah dan pelabuhan tersebut membawa kemajuan terhadap warga sekitarnya. Berdirinya perusahan pelabuhan di suatu daerah akan membawa kemajuan terhadap warga yang ada disekitar daerah tersebut. Pemikiran tersebut berdasarkan pada pandangan terhadap perusahaan pelabuhan yang telah dibangun disuatu wilayah, dan berdirinya perusahan pelabuhan ini berdampak pada perubahan sosial ekonomi yang lebih baik disekitar wilayah pelabuhan. Lebih tepatnya perusahaan pelabuhan akan membawa arus investasi, membongkar isolasi warga, serta membuka akses masyarakat terhadap dunia luar. Desa Mengare merupakan salah satu wilayah yang masuk dalam lingkup pembangunan perusahaan pelabuhan Pelindo III (JIIPE) yang terletak di Kecamatan Bungah Kabupaten Gresik Provinsi Jawa Timur. Melihat begitu besarnya potensi kesejahteraan yang akan diperoleh masyarakat sekitar, diperlukan suatu upaya yang maksimal untuk memanfaatkan potensi wilayah tersebut melalui penilaian faktorfaktor yang mempengaruhi potensi Desa Mengare dan strategi apa saja yang harus dilakukan dalam mengelola potensi Desa
Mengare dengan adanya pembangunan Pelindo III (JIIPE) Wilayah Gresik.

\section{METODE PENELITIAN}

Dalam penelitian ini, terdiri dari beberapa tahap penelitian, yaitu tahap pendahuluan, tahap pengumpulan data, tahap pengolahan data, dan tahap analisis data serta tahap kesimpulan dan saran. Tahap Pendahuluan, yaitu tahap memunculkan suatu permasalahan dan mengidentifikasi permasalah tersebut, dengan cara observasi langsung di Desa Mengare Kecamatan Bungah Kabupaten Gresik. Identifikasi masalah ini dilakukan pengamatan secara langsung di Desa Mengare Kecamatan Bungah Kabupaten Gresik gunanya untuk mengkerucutkan rumusan permasalahan

Tahap selanjutnya ialah pengumpulan data. Data yang dikumpulkan dalam penelitian ini ada dua macam, yaitu data primer dan data sekunder. Data primer didapat dengan cara observasi dan wawancara serta penyebaran kuesioner langsung kepada responden yaitu masyarakat warga Desa Mengare, sedangkan data sekunder didapat dengan mempelajari, meneliti, serta menelaah literatur yang ada kaitannya dengan masalah yang diteliti. Data ini berupa potensi Desa Mengare terhadap adanya pembangunan pelabuhan Pelindo III (JIIPE).

Tahap selanjutnya merupakan tahap pengolahan data. Pada tahap ini, terbagi menjadi tiga pengujian, yaitu uji kecukupan data, uji validitas data, dan uji reliabilitas data. Uji kecukupan data digunakan untuk menentukan jumlah responden yang dibutuhkan dalam penelitian apakah jumlah responden sudah mencukupi atau belum. Uji validitas digunakan untuk mengetahui apakah data yang diperoleh sudah valid atau belum, sedangkan uji reliabilitas digunakan untuk mengetahui apakah data yang diperoleh sudah reliable atau belum.

Tahap selanjutnya adalah tahap analisis data. Pada tahap ini, digunakan dua jenis analisis data, yaitu anlisis SWOT dan Delphi. Analisis SWOT digunakan untuk mengungkapkan faktor internal dan faktor eksternal yang meliputi kekuatan, kelemahan, kesempatan dan ancaman dengan cara memaksimalkan kekuatan dan peluang, sekaligus meminimalkan kelemahan dan ancaman yang ada sehingga dapat dicapai 
keseimbangan antara kondisi internal dengan kondisi eksternal terkait adanya pembangunan pelabuhan Pelindo III (JIIPE). Analisis Deilphi digunakan untuk wawancara terhadap responden yang dianggap ahli dapat ditarik simpulan tentang strategi apa yang tepat untuk digunakan masyarakat Mengare dalam upaya pemanfaatan potensi Desa Mengare. Akan tetapi, apabila belum memenuhi tujuan penelitian, data ditinjau ulang dan diperbaiki jika ada data yang salah dalam penelitian ini.

Tahap yang terakhir merupakan kesimpulan dan saran, setelah semua proses telah dilakukan maka tahap ini dapat menyimpulkan hasil akhir dari pengolahan data dan menyampaikan saran jika ditemukan kekurangan.

\section{HASIL DAN PEMBAHASAN}

Desa Mengare dalam mengembangkan potensi Sumber Daya Alam berupa hasil desa, hasil laut dan pariwisata serta Sumber Daya Manusia, meliputi pendidikan dan pekerjaan harus diprioritaskan karena dengan memprioritaskan pengembangan potensi tersebut dapat menumbuhkan titik perekonomian sehingga masyarakat mampu bersaing pada era globalisasi ekonomi untuk meningkatkan kesejahteraan Desa Mengare dengan menggunakan pendekatan analisis SWOT dan Delphi. Analisis SWOT digunakan untuk menjaring persepsi dan penilaian ahli terhadap faktor internal dan eksternal terkait potensi Desa Mengare terhadap adanya pembangunan pelabuhan Pelindo III (JIIPE) sehingga pada akhirnya didapatkan faktor kekuatan, faktor kelemahan, faktor peluang, dan faktor ancaman. Dari penilaian bobot IFAS (Internal Factor Analysis System) dan EFAS (External Factor Analysis System), didapatkan beberapa alternatif strategi yang dapat digunakan dalam upaya pemanfaatan potensi Desa Mengare.

Setelah dipaparkan beberapa alternatif strategi, perlu dilakukan pemilihan prioritas berdasarkan kriteria yang ditetapkan. Penentuan prioritas ini perlu dilakukan karena untuk melakukan seluruh strategi yang telah diperoleh melalui analisis SWOT membutuhkan sumber daya yang sangat besar sehingga tidak semua strategi dapat terlaksana. Oleh sebab itu, untuk memprioritaskan strategi tersebut dilakukan pendekatan Delphi.

\subsection{Hasil Analisis SWOT}

Berdasarkan perhitungan, diketahui bahwasannya nilai banchmark atau rata-rata dari seluruh faktor internal adalah sebesar 3,73. Faktor-faktor internal tersebut kemudian dibagi menjadi dua bagian, yaitu faktor internal yang nilai rata-ratanya diatas banchmark, dikelompokkan sebagai kekuatan (Strength), dan faktor internal yang nilai rata-ratanya dibawah nilai banchmark, dikelompokkan sebagai kelemahan (Weakness).

Tabel 3.1 Ringkasan Pembobotan Faktor-faktor Internal

\begin{tabular}{|c|c|c|}
\hline No & Strength & $\begin{array}{l}\text { Rata- } \\
\text { rata }\end{array}$ \\
\hline 1. & $\begin{array}{l}\text { Letak geografis posisi Desa } \\
\text { Mengare menguntungkan } \\
\text { untuk pertumbuhan ekonomi } \\
\text { dan distribusi barang/jasa }\end{array}$ & 3,68 \\
\hline 2. & $\begin{array}{l}\text { Kualitas dan kuantitas Sumber } \\
\text { Daya Manusiamampu untuk } \\
\text { bersaing dalam perekrutan } \\
\text { tenaga kerja pelabuhan }\end{array}$ & 3,88 \\
\hline 4. & 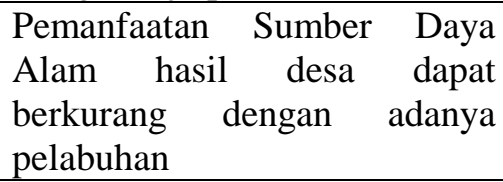 & 3,66 \\
\hline 6. & $\begin{array}{lr}\text { Etos kerja, keuletan, dan jiwa } \\
\text { kewirausahaan di } & \text { sektor } \\
\text { perekonomian } & \text { mikro } \\
\text { meningkat dengan adanya } \\
\text { pelabuhan }\end{array}$ & 3,62 \\
\hline \multirow[t]{2}{*}{7.} & $\begin{array}{l}\text { Pemanfaatan Sumber Daya } \\
\text { Alam hasil laut meningkat } \\
\text { dengan adanya pelabuhan }\end{array}$ & 4 \\
\hline & Weakness & $\begin{array}{l}\text { Rata- } \\
\text { rata }\end{array}$ \\
\hline 3. & $\begin{array}{l}\text { Penentuan skala prioritas } \\
\text { potensi desa mengare yang } \\
\text { dapat dikelola oleh masyarakat } \\
\text { dengan adanya pelabuhan }\end{array}$ & 3,78 \\
\hline 5. & $\begin{array}{l}\text { Pemanfaatan Sumber Daya } \\
\text { Alam pariwisata yang dikelola } \\
\text { masyarakat dengan adanya } \\
\text { pelabuhan labuhan }\end{array}$ & 3,72 \\
\hline 8. & $\begin{array}{lr}\text { Upaya } & \text { masyarakat } \\
\text { mensosialisasikan potensi desa } \\
\text { kepada pihak } \\
\text { pelabuhan }\end{array}$ & 3,7 \\
\hline
\end{tabular}




\begin{tabular}{|c|l|c|}
\hline 9. & $\begin{array}{l}\text { Tingkat partisipasi masyarakat } \\
\text { dalam mengelola potensi desa } \\
\text { dengan adanya pelabuhan }\end{array}$ & 3,7 \\
\hline 10. & $\begin{array}{l}\text { Tingkat Pendidikan masyarakat } \\
\text { untuk mengelola potensi desa } \\
\text { dengan adanya pelabuhan }\end{array}$ & 3,54 \\
\hline & Rata-rata & $\mathbf{3 , 7 3}$ \\
\hline
\end{tabular}

a) Faktor Kekuatan (strength)

Berdasarkan hasil rekapitulasi kuisioner dan penilaian responden, faktor-faktor yang menjadi kekuatan dalam upaya meningkatkan potensi Desa Mengare adalah sebagai berikut.

1. Letak posisi geografis Desa Mengare menguntungkan untuk pertumbuhan ekonomi dan distribusi barang/jasa. Posisi geografis Desa Mengare mendapatkan nilai rata-rata sebesar 3,68. Desa Mengare terletak di pesisir pantai selat Madura dengan pendapatan hasil laut yang lumayan banyak.

2. Kualitas dan kuantitas sumber daya manusia mampu untuk bersaing dalam perekrutan tenaga kerja pelabuhan. Faktor kualitas dan kuantitas sumber daya manusia di Desa Mengare mendapatkan nilai rata-rata sebesar 3,88. Jumlah penduduk Desa Mengare yang cukup banyak tentu menjadikan modal bagi masyarakat untuk dapat mensejahterakan Desa dalam bersaing dengan masyarakat luar.

3. Pemanfaatan sumber daya alam hasil desa dapat berkurang dengan adanya pelabuhan. Faktor ini mendapatkan nilai rata-rata sebesar 3,66. Pendapatan hasil desa Desa Mengare cukup memuaskan, sebagian masyarakat Desa Mengare juga bekerja sebagai petani kacangkacangan dan umbi-umbian.

4. Etos kerja, keuletan dan jiwa kewirausahaan di sektor perekonomian mikro dengan adanya pelabuhan, faktor ini mendapatkan nilai ratarata sebesar 3,62. Beberapa masyarakat Desa Mengare juga banyak yang menjalankan usaha sendiri dari hasil pengelolaan sumber daya yang ada.

5. Pemanfaatan sumber daya alam hasil laut meningkat dengan adanya pelabuhan. Faktor ini mendapatkan nilai rata-rata sebesar 4. Desa Mengare terkenal dengan Desa penghasil rajungan serta ikan bandeng yang sangat enak dikalangan wilayah Jawa Timur.

b) Faktor Kelemahan (Weakness)
Berdasarkan hasil rekapitulasi kuisioner dan penilaian responden, faktor-faktor yang menjadi kelemahan dalam upaya peningkatan potensi Desa Mengare adalah sebagai berikut.

1. Penentuan skala prioritas potensi Desa Mengare yang dapat dikelola oleh masyarakat dengan adanya pelabuhan. Faktor ini mendapatkan nilai rata-rata sebesar 3,78. Penentuan skala prioritas adalah hal yang sangat penting untuk dilakukan karena dengan adanya prioritas pemanfaatan potensi Desa Mengare kita dapat mengetahui faktor potensi desa apa yang bedampak langsung pada peningkatan kesejahteraan masyarakat serta lebih mendahulukan penanganannya dibandingkan dengan faktor-faktor lainnya.

2. Pemanfaatan sumber daya alam pariwisata yang dikelola masyarakat dengan adanya pelabuhan. Faktor ini mendapatkan nilai ratarata sebesar 3,72. Pemanfaatan sumber daya alam pariwisata di Desa Mengare masih kurang baik dikarenakan belum adanya program pemerintah yang direalisasikan untuk membangun tempat-tempat pariwisata di Desa Mengare. Beberapa tempat pariwisata yang memiliki potensi sangat besar terhadap tititk tumbuh ekonomi masyarakat Desa Mengare, yaitu benteng peninggalan belanda, hutan mangrove dan pantai pasir putih.

3. Upaya masyarakat mensosialisasikan potensi desa kepada pihak investor pelabuhan. Faktor ini mendapatkan nilai rata-rata sebesar 3,7. Desa Mengare memiliki potensi yang beragam mulai dari sumber daya alam hasil desa, hasil laut, sampai dengan pariwisata.

4. Tingkat partisipasi masyarakat dalam mengelola potensi desa dengan adanya pelabuhan. Faktor ini mendapatkan nilai ratarata sebesar 3,7. Kemajuan tingkat kesejahteraan masyarakat sangat memerlukan adanya dukungan dan partisipasi masyarakat dalam perencanaan, pelaksanaan serta pengawasan untuk meningkatkan potensi desa yang akan dikelola.

5. Tingkat pendidikan masyarakat untuk mengelola potensi desa dengan adanya pelabuhan. Faktor ini mendapatkan nilai ratarata sebesar 3,54. Peningkatan pengelolaan potensi desa perlu adanya pengetahuan yang memadai. Oleh sebab itu, tingkat pendidikan masyarakat sangat penting untuk kemajuan 
potensi desa. Pendidikan merupakan dasar kekuatan untuk bersaing dalam pengelolaan potensi desa yang ada, tidak hanya itu tingkat pendidikan juga menjadi kriteria yang penting bagi perusahaan untuk penerimaan tenaga kerja.

Tabel 3.2 Ringkasan Pembobotan Faktor Eksternal

\begin{tabular}{|l|l|c|}
\hline & \multicolumn{1}{|c|}{ Opportunity } & $\begin{array}{c}\text { Rata- } \\
\text { rata }\end{array}$ \\
\hline 1. & $\begin{array}{l}\text { Peluang lapangan pekerjaan } \\
\text { untuk masyarakat terbuka } \\
\text { luas dengan adanya } \\
\text { pembangunan pelabuhan }\end{array}$ & 3,92 \\
\hline 2. & $\begin{array}{l}\text { Peluang membuka berbagai } \\
\text { macam usaha terbuka luas } \\
\text { dengan adanya pelabuhan }\end{array}$ & 3,56 \\
\hline 3. & $\begin{array}{l}\text { Pemberdayaan UMKM } \\
\text { meningkat dengan adanya } \\
\text { pelabuhan }\end{array}$ & 3,96 \\
\hline 6. & $\begin{array}{l}\text { Bentuk kerjasama antara } \\
\text { pihak pelabuhan dengan } \\
\text { masyarakat }\end{array}$ & 3,86 \\
\hline 7. & $\begin{array}{l}\text { Program pemerintah dalam } \\
\text { mensejahterakan } \\
\text { masyarakat dengan adanya } \\
\text { pelabuhan }\end{array}$ & 3,82 \\
\hline 8. & $\begin{array}{l}\text { Kerjasama antar desa di } \\
\text { lingkungan Kabupaten } \\
\text { Gresik semakin meningkat } \\
\text { dengan adanya pelabuhan }\end{array}$ & 3,64 \\
\hline 10. & $\begin{array}{l}\text { Pengaruh pembangunan } \\
\text { infrastruktur pelabuhan } \\
\text { terhadap } \\
\text { potensi desa }\end{array}$ & 3,62 \\
\hline pemanfaatan \\
\hline 5. & $\begin{array}{l}\text { Dampak globalisasi, pasar } \\
\text { bebas dan keterbukaan } \\
\text { ekonomi dunia dengan } \\
\text { adanya pelabuhan }\end{array}$ & $\begin{array}{l}\text { Kondisi sosial, politik dan } \\
\text { ekonomi pihak pelabuhan } \\
\text { dengan masyarakat }\end{array}$ \\
\hline 9. & $\begin{array}{l}\text { Investasi dilingkungan } \\
\text { masyarakat dengan adanya } \\
\text { pelabuhan }\end{array}$ & 3,96 \\
\hline & rata \\
\hline 5,82 \\
\hline
\end{tabular}

c) Faktor peluang/kesempatan (Opportunity)
Berdasarkan hasil rekapitulasi kuisioner dari penilaian responden, faktor-faktor yang menjadi peluang dalam upaya meningkatkan potensi Desa Mengare adalah sebagai berikut.

1. Peluang lapangan pekerjaan untuk masyarakat terbuka luas dengan adanya pembanguanan pelabuhan. Faktor ini mendapatkan nilai ratarata sebesar 3,92. Pembanguanan pelabuhan sangat berpengaruh terhadap peningkatan kesejahteraan di wilayah sekitarnya karena dengan adanya pembangunan pelabuhan terbuka pula lapangan kerja untuk bekerja di pelabuhan.

2. Peluang membuka berbagai macam usaha terbuka luas dengan adanya pelabuhan. Faktor ini mendapatkan nilai rata-rata sebesar 3,56. Disamping pembangunan pelabuhan membuat terbukanya lapangan pekerjaan juga membuka peluang untuk membuka berbagai macam usaha, dengan adanya pembangunan pelabuhan ini kemungkinan di sekitar pelabuhan akan dibangun berbagai macam gedung seperti pergudangan, hotel penginapan, restoran, mal dan lain sebagainya.

3. Pemberdayaan UMKM meningkat dengan adanya pelabuhan. Faktor ini mendapatkan nilai rata-rata sebesar 3,96. Pembangunan pelabuhan dapat mempengaruhi tingkat pendapatan dan pemasaran produk-produk usaha kecil menengah di wilayah sekitarnya.

4. Bentuk kerjasama antara pihak pelabuhan dengan masyarakat. Faktor ini mendapatkan nilai rata-rata sebesar 3,86. Bentuk kerjasama antara pihak pelabuhan dengan masyarakat Desa Mengare salah satunya ialah tidak membatasi masyarakat Desa Mengare untuk mendaftar bekerja di pelabuhan Pelindo III (JIIPE). Akan tetapi, pihak pelabuhan memberikan syarat menempatkan sesuai dengan kemampuan mereka.

5. Program pemerintah dalam mensejahterakan masyarakat dengan adanya pelabuhan. Faktor ini mendapatkan nilai rata-rata sebesar 3,82. Pembangunan pelabuhan Pelindo III (JIIPE) ini membuat pemerintah merancang berbagai program untuk mengelola potensi wilayah disekitar pembanguan pelabuhan.

6. Kerjasama antardesa di lingkungan Kabupaten Gresik semakin meningkat dengan adanya pelabuhan. Faktor ini mendapatkan 
nilai rata-rata sebesar 3,64. Kerjasama antar desa di wilayah Kabupaten Gresik sangat penting untuk menunjang pengelolaan potensi desa yang ada.

7. Pengaruh pembangunan infrastruktur pelabuhan terhadap pemanfaatan potensi desa. Faktor ini mendapatkan nilai rata-rata sebesar 3,62. Adanya pembangunan pelabuhan tidak luput dari pembangunan infrastruktur penunjang beroprasinya pelabuhan dengan dibanguannya infrastruktur penunjang pelabuhan memberikan dampak positif terhadap wilayah sekitarnya

\section{d) Faktor Ancaman (Threat)}

Berdasarkan hasil rekapitulasi kuisioner dari penilaian responden, faktor-faktor yang menjadi ancaman dalam upaya meningkatkan potensi Desa Mengare adalah sebagai berikut.

1. Dampak globalisasi, pasar bebas, dan keterbukaan ekonomi dunia dengan adanya pelabuhan. Faktor ini mendapatkan nilai ratarata sebesar 3,96. Pada era globalisasi, peran suatu daerah sangat penting bagi kegiatan perekonomian. Oleh karena itu, dibutuhkan persiapan yang sangat matang dalam menghadapi arus perekonomian global.

2. Kondisi sosial, politik, ekonomi pihak pelabuhan dengan masyarakat. Faktor ini mendapatkan nilai rata-rata sebesar 3,96.

3. Investasi dilingkungan masyarakat dengan adanya pelabuhan. Faktor ini mendapatkan nilai rata-rata sebesar 3,86. Investasi juga merupakan salah satu faktor penting dalam membantu terciptanya titik pertumbuhan ekonomi.

Setelah

dikelompokkan

kelemahan,

dikelompokkan menjadi peluang dan ancaman, langkah selanjutnya adalah pembobotan IFASEFAS.
Tabel 3.3 Penilaian Bobot Matriks EFAS-IFAS

\begin{tabular}{|c|c|c|c|c|c|}
\hline \multirow{6}{*}{ 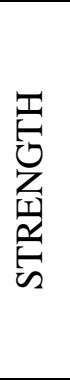 } & & $\begin{array}{c}\text { Rata- } \\
\text { rata }\end{array}$ & $\begin{array}{c}\text { Bobo } \\
t\end{array}$ & $\begin{array}{c}\text { Nila } \\
\text { i }\end{array}$ & $\begin{array}{c}\text { Bobo } \\
\text { tx } \\
\text { nilai }\end{array}$ \\
\hline & 1 & 3,68 & 0,08 & 4 & 0,32 \\
\hline & 2 & 3,88 & 0,18 & 2 & 0,36 \\
\hline & 4 & 3,66 & 0,06 & 3 & 0,18 \\
\hline & 6 & 3,62 & 0,03 & 3 & 0,09 \\
\hline & 7 & 4 & 0,20 & 1 & 0,20 \\
\hline \multirow{8}{*}{ 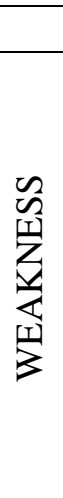 } & & Total S & $\mathbf{0 , 5 5}$ & 13 & 1,15 \\
\hline & & $\begin{array}{c}\text { Rata- } \\
\text { rata }\end{array}$ & $\begin{array}{c}\text { Bobo } \\
t\end{array}$ & $\begin{array}{c}\text { Nila } \\
\text { i }\end{array}$ & $\begin{array}{c}\text { Bobo } \\
\text { tx } \\
\text { nilai }\end{array}$ \\
\hline & 3 & 3,78 & 0,12 & 1 & 0,12 \\
\hline & 5 & 3,72 & 0,11 & 1 & 0,11 \\
\hline & 8 & 3,7 & 0,10 & 2 & 0,20 \\
\hline & 9 & 3,7 & 0,10 & 2 & 0,20 \\
\hline & 10 & 3,54 & 0,02 & 2 & 0,04 \\
\hline & & $\begin{array}{c}\text { Total } \\
\text { W }\end{array}$ & $\mathbf{0 , 4 5}$ & 8 & 0,67 \\
\hline
\end{tabular}

Dari tabel 3.3, dapat dilihat bahwa faktor kelemahan yang mendapatkan nilai rata-rata terendah adalah tingkat pendidikan masyarakat Desa Mengare dengan nilai rata-rata sebesar 3,54. Hal ini menurut responden merupakan kelemahan terbesar Desa Mengare karena ratarata masyarakat Desa Mengare banyak yang lulusan SMA. Oleh karena itu, tingkal pendidikan ini prioritas untuk diperbaiki.

Faktor peluang yang memiliki nilai rata-rata tertinggi adalah peningkatan pemberdayaan UMKM di Desa Mengare dengan nilai rata-rata 3,96. Dengan ditingkatnya pemberdayaan UMKM, akan membangun dengan cepat titik tumbuh perekonomian Desa Mengare. Adapun aspek-aspek yang harus diperhatikan adalah pendanaan, sarana dan prasarana, informasi usaha, kemitraan, perizinan usaha, kesempatan berusaha, promosi dagang, serta dukungan kelembagaan. Hal ini dapat memberikan peluang kepada usah kecil dan menengah yang saat ini mulai berkembang di Desa Mengare, tidak hanya usaha yang berkembang saja akan tetapi usaha yang sebelumnya mengalami mati suri juga harus diberi kehidupan kembali.

Faktor ancaman yang memiliki nilai ratarata terendah adalah investasi swasta dilingkungan masyarakat, dengan nilai rata-rata sebesar 3,86. Artinya, investasi swasta yang 
ditanamkan di kalangan masyarakat akan sangat membahayakan bagi perekonomian, karena jika perekonomian dikuasai oleh pihak swasta maka yang mengatur seluruh aliran perdangan adalah pihak swasta dan kemungkinan besar masyarakat luar akan lebih di prioritaskan untuk bekerja diwilayah tersebut dari pada masyarakat lokal sendiri.

Tabel 3.4 Pembobotan Hasil Kuesioner SWOT

\begin{tabular}{|c|c|c|}
\cline { 2 - 3 } \multicolumn{1}{c|}{} & $\mathbf{S = 1 , 1 5}$ & $\mathbf{W}=\mathbf{0 , 6 7}$ \\
\hline $\mathbf{O}=\mathbf{0 , 8 8}$ & $\mathrm{SO}=2,03$ & $\mathrm{WO}=1,55$ \\
\hline $\mathbf{T}=\mathbf{0 , 6 2}$ & $\mathrm{ST}=1,77$ & $\mathrm{WT}=1,29$ \\
\hline
\end{tabular}

Pada tabel 4.4 dapat dilihat hasil pembobotan kuisioner berdasarkan tabel matriks EFAS-IFAS. Strategi Strength - Opportunity (SO) mendapatkan nilai 2,30. Strategi Weakness Opportunity mendapatkan nilai 1,55. Strategi Strength - Threat (ST) mendapatkan nilai 1,77. Serta strategi Weakness - Threat (WT) mendapatkan nilai 1,29.

Tabel 3.5 Urutan Alternatif Strategi SWOT

\begin{tabular}{|c|l|c|}
\hline Prioritas & \multicolumn{1}{|c|}{ Strategi } & $\begin{array}{c}\text { Bobot } \\
\text { Nilai }\end{array}$ \\
\hline I & $\begin{array}{l}\text { Strength } \\
\text { Opportunity (SO) }\end{array}$ & 2,30 \\
\hline II & $\begin{array}{l}\text { Strength-Threat } \\
\text { (ST) }\end{array}$ & 1,77 \\
\hline III & $\begin{array}{l}\text { Weakness - } \\
\text { Opportunity } \\
\text { WO) }\end{array}$ & 1,55 \\
\hline IV & $\begin{array}{l}\text { Weakness } \\
\text { Threat (WT) }\end{array}$ & 1,29 \\
\hline
\end{tabular}

Dari hasil interaksi IFAS-EFAS, yang menghasilkan alternatif strategi yang mendapat bobot paling tinggi adalah Streght-Opportunity (SO), yang dapat diartikan sebagai strategi menggunakan kekuatan untuk memanfaatkan peluang/kesempatan yang ada. Kondisi ini menguntungkan bagi Desa Mengare karena dari sisi faktor internal, Desa Mengare memiliki kekuatan yang lebih besar dari pada kelemahannya, sedangkan penilaian dari sisi faktor eksternal peluang yang ada jauh lebih besar dari pada ancaman dalam upaya pemanfaatan potensi Desa Mengare. Perumusan strategi diperoleh melalui kombinasi faktor elemen S, W, O, dan T.
Tabel 3.6 Strategi Prioritas I: StrengthOpprtunity (SO)

\begin{tabular}{|c|c|}
\hline & \\
\hline $\begin{array}{l}\text { 1. Letak geografis } \\
\text { posisi Desa } \\
\text { Mengare } \\
\text { menguntungkan } \\
\text { untuk pertumbuhan } \\
\text { ekonomi dan } \\
\text { distribusi } \\
\text { barang/jasa. } \\
\text { 2. Kualitas dan } \\
\text { kuantitas Sumber } \\
\text { Daya } \\
\text { Manusiamampu } \\
\text { untuk bersaing } \\
\text { dalam perekrutan } \\
\text { tenaga kerja } \\
\text { pelabuhan } \\
\text { 3. Pemanfaatan } \\
\text { Sumber Daya Alam } \\
\text { hasil desa dapat } \\
\text { berkurang dengan } \\
\text { adanya pelabuhan } \\
\text { 4. Etos kerja, } \\
\text { keuletan, dan jiwa } \\
\text { kewirausahaan di } \\
\text { sektor } \\
\text { perekonomian } \\
\text { mikro meningkat } \\
\text { dengan adanya } \\
\text { pelabuhan } \\
\text { 5. Pemanfaatan } \\
\text { Sumber Daya Alam } \\
\text { hasil laut } \\
\text { meningkat dengan } \\
\text { adanya pelabuhan }\end{array}$ & $\begin{array}{l}\text { 1. Peluang lapangan } \\
\text { pekerjaan untuk } \\
\text { masyarakat } \\
\text { terbuka luas } \\
\text { dengan adanya } \\
\text { pembangunan } \\
\text { pelabuhan } \\
\text { 2. Peluang membuka } \\
\text { berbagai macam } \\
\text { usaha terbuka luas } \\
\text { dengan adanya } \\
\text { pelabuhan } \\
\text { 3. Pemberdayaan } \\
\text { UMKM } \\
\text { meningkat dengan } \\
\text { adanya pelabuhan } \\
\text { 4. Bentuk kerjasama } \\
\text { antara pihak } \\
\text { pelabuhan dengan } \\
\text { masyarakat. } \\
\text { 5. Program } \\
\text { pemerintah dalam } \\
\text { mensejahterakan } \\
\text { masyarakat } \\
\text { dengan adanya } \\
\text { pelabuhan. } \\
\text { 6. Kerjasama antar } \\
\text { desa di } \\
\text { lingkungan } \\
\text { Kabupaten Gresik } \\
\text { semakin } \\
\text { meningkat dengan } \\
\text { adanya pelabuhan. } \\
\text { 7. Pengaruh } \\
\text { pembangunan } \\
\text { infrastruktur } \\
\text { pelabuhan } \\
\text { terhadap } \\
\text { pemanfaatan } \\
\text { potensi desa. } \\
\end{array}$ \\
\hline \multicolumn{2}{|c|}{ Strategi SO (Strength - Opportunity) } \\
\hline \multicolumn{2}{|c|}{$\begin{array}{l}\text { 1. Memanfaatkan letak posisi geografis Desa } \\
\text { Mengare yang dekat dengan pelabuhan } \\
\text { sehingga menguntungkan untuk terbuka } \\
\text { peluang kerja, pertumbuhan ekonomi dan } \\
\text { distribusi barang/jasa } \\
\text { 2. Kualitas dan kuantitas masyarakat mampu }\end{array}$} \\
\hline
\end{tabular}


untuk bersaing dalam perekrutan lapangan pekerjaan pelabuhan

3. Memanfaatkan sumber daya alam hasil desa dengan meningkatkan memberdayakan UMKM untuk di promosikan kepada pihak/tenagakerja pelabuha

4. Meningkatkan kewirausahaan di sektor perekonomian mikro dan bekerjasama dengan desa di lingkungan Kabupaten Gresik dalam memasarkan produk

5. Memanfaatkan sumber daya alam hasil laut untuk dijadikan produk usaha serta dipasarkan ke wilayah pelabuhan

Meskipun strategi SO merupakan alternatif strategi terbaik yang memiliki nilai pembobotan paling tinggi, belum tentu semua strategi-strategi tersebut dapat dilaksanakan secara optimal. Sehingga, perlu dilakukan beberapa prioritas apabila dalam pelaksanaannya secara bersama-sama menemui kendala sumber daya. Penentuan prioritas kebijakan dari beberapa strategi kebijakan Strength-Opportunity (SO) yang dihasilkan melalui analisis SWOT pada penulisan ini dilakukan dengan metode Delphi.

\subsection{Hasil Analisis Delphi}

Untuk mencari faktor-faktor yang dipergunakan sebagai konsep peningkatan potensi Desa Mengare terhadap adanya pembangunan pelabuhan Pelindo III (JIIPE), akan diketahui bagaimana strategi arahan/saran yang akan digunakan dalam konsep tersebut. Alat analisis yang digunakan adalah analisis Delphi, karena melalui analisa ini nantinya akan dilakukan eksplorasi terhadap potensi Desa Mengare yang memiliki pengaruh terhadap peningakatan kesejahteraan masyarakat Desa Mengare. Adapun faktor-faktor yang berpengaruh disebabkan oleh adanya pembangunan pelabuhan Pelindo III (JIIPE). Dalam penelitian ini, terdapat beberapa bentuk iterasi/tahapan analisis Delphi untuk memperoleh data yang akurat dari para responden, antara lain (1) Iterasi I adalah menguji variabel yang dihasilkan dari kajian teori, yang selanjutnya menghasilkan persetujuan awal terhadap variabel tersebut sebagai faktor yang akan diteliti lebih lanjut; (2) Iterasi II adalah mengeksplorasi faktor-faktor potensi Desa Mengare yang berpengaruh terhadap adanya pembangunan pelabuhan Pelindo III (JIIPE); (3) Iterasi III adalah menentukan faktor-faktor strategi yang akan dipakai untuk merumuskan konsep pemanfaatan potensi Desa Mengare.

Tahapan analisa Delphi, Iterasi I adalah menguji faktor-faktor yang dihasilkan dari kajian pustaka/teori dari analisis SWOT variabel yang didapat di ujikan dengan wawancara langsung kepada Kepala Desa 3 kelurahan apakah variabel yang di dapat sudah tepat untuk dijadikan kuesioner. Selanjutnya, Iterasi II adalah untuk memberikan kesempatan penilaian kepada responden terhadap semua variabel dan faktor yang dihasilkan dari kuisioner SWOT.

Tabel 3.7 Penilaian Responden terhadap Faktorfaktor Potensi

\begin{tabular}{|c|c|c|c|c|c|c|}
\hline \multirow[b]{2}{*}{ No } & \multirow[b]{2}{*}{ Faktor-faktor } & \multicolumn{5}{|c|}{$\begin{array}{c}\text { Penilaian } \\
\text { Responden }\end{array}$} \\
\hline & & $\begin{array}{l}\mathrm{S} \\
\mathrm{K} \\
\mathrm{B}\end{array}$ & $\begin{array}{l}\mathrm{K} \\
\mathrm{B}\end{array}$ & $\mathrm{N}$ & $\mathrm{B}$ & $\begin{array}{l}\text { S } \\
\text { B }\end{array}$ \\
\hline I & Faktor Internal & & & & & \\
\hline 1. & $\begin{array}{l}\text { Apakah letak } \\
\text { geografis posisi } \\
\text { Desa Mengare } \\
\text { menguntungkan } \\
\text { untuk } \\
\text { pertumbuhan } \\
\text { ekonomi dan } \\
\text { distribusi } \\
\text { barang/jasa. }\end{array}$ & & & $\mathrm{N}$ & & \\
\hline 2. & $\begin{array}{l}\text { Apakah kualitas } \\
\text { dan kuantitas } \\
\text { Sumber Daya } \\
\text { Manusiamampu } \\
\text { untuk bersaing } \\
\text { dalam perekrutan } \\
\text { tenaga kerja } \\
\text { pelabuhan. }\end{array}$ & & & & & $\begin{array}{l}\mathrm{S} \\
\mathrm{B}\end{array}$ \\
\hline 3. & $\begin{array}{l}\text { Bagaimana } \\
\text { penentuan skala } \\
\text { prioritas potensi } \\
\text { desa mengare } \\
\text { yang dapat } \\
\text { dikelola oleh } \\
\text { masyarakat } \\
\text { dengan adanya } \\
\text { pelabuhan. }\end{array}$ & & $\begin{array}{l}K \\
B\end{array}$ & & & \\
\hline
\end{tabular}




\begin{tabular}{|c|c|c|c|c|}
\hline 4. & $\begin{array}{l}\text { Apakah } \\
\text { pemanfaatan } \\
\text { Sumber Daya } \\
\text { Alam hasil desa } \\
\text { dapat berkurang } \\
\text { dengan adanya } \\
\text { pelabuhan. }\end{array}$ & & & B \\
\hline 5. & $\begin{array}{l}\text { Bagaimana } \\
\text { pemanfaatan } \\
\text { Sumber Daya } \\
\text { Alam pariwisata } \\
\text { yang dikelola } \\
\text { masyarakat } \\
\text { dengan adanya } \\
\text { pelabuhan. }\end{array}$ & $\begin{array}{l}\mathrm{K} \\
\mathrm{B}\end{array}$ & & \\
\hline 6. & $\begin{array}{l}\text { Apakah Etos } \\
\text { kerja, keuletan, } \\
\text { dan jiwa } \\
\text { kewirausahaan di } \\
\text { sektor } \\
\text { perekonomian } \\
\text { mikro meningkat } \\
\text { dengan adanya } \\
\text { pelabuhan. }\end{array}$ & & & B \\
\hline 7. & $\begin{array}{l}\text { Apakah } \\
\text { pemanfaatan } \\
\text { Sumber Daya } \\
\text { Alam hasil laut } \\
\text { meningkat dengan } \\
\text { adanya pelabuhan. }\end{array}$ & & & B \\
\hline 8. & $\begin{array}{l}\text { Bagaimana upaya } \\
\text { masyarakat } \\
\text { mensosialisasikan } \\
\text { potensi desa } \\
\text { kepada pihak } \\
\text { investor } \\
\text { pelabuhan. }\end{array}$ & $\begin{array}{l}\mathrm{K} \\
\mathrm{B}\end{array}$ & & \\
\hline 9. & $\begin{array}{l}\text { Bagaimana tingkat } \\
\text { partisipasi } \\
\text { masyarakat dalam } \\
\text { mengelola potensi } \\
\text { desa dengan } \\
\text { adanya pelabuhan. }\end{array}$ & & $\mathrm{N}$ & \\
\hline 10. & $\begin{array}{l}\text { Bagaimana tingkat } \\
\text { pendidikan } \\
\text { masyarakat untuk } \\
\text { mengelola potensi } \\
\text { desa dengan } \\
\text { adanya pelabuhan. }\end{array}$ & $\begin{array}{l}\mathrm{K} \\
\mathrm{B}\end{array}$ & & \\
\hline
\end{tabular}

\begin{tabular}{|c|c|c|c|c|c|c|}
\hline \multirow[b]{2}{*}{ No } & \multirow[b]{2}{*}{ Faktor-faktor } & \multicolumn{5}{|c|}{$\begin{array}{c}\text { Penilaian } \\
\text { Responden }\end{array}$} \\
\hline & & $\begin{array}{l}\mathrm{S} \\
\mathrm{K} \\
\mathrm{B}\end{array}$ & $\begin{array}{l}\mathrm{K} \\
\mathrm{B}\end{array}$ & $\mathrm{N}$ & $\mathrm{B}$ & $\begin{array}{l}\text { S } \\
\text { B }\end{array}$ \\
\hline I & Faktor Eksternal & & & & & \\
\hline 1. & $\begin{array}{l}\text { Apakah peluang } \\
\text { lapangan } \\
\text { pekerjaan untuk } \\
\text { masyarakat } \\
\text { terbuka luas } \\
\text { dengan adanya } \\
\text { pembangunan } \\
\text { pelabuhan. }\end{array}$ & & & & & $\begin{array}{l}\text { S } \\
\text { B }\end{array}$ \\
\hline 2. & $\begin{array}{l}\text { Apakah peluang } \\
\text { membuka } \\
\text { berbagai macam } \\
\text { usaha terbuka luas } \\
\text { dengan adanya } \\
\text { pelabuhan. }\end{array}$ & & & & $\mathrm{B}$ & \\
\hline 3. & $\begin{array}{l}\text { Apakah } \\
\text { pemberdayaan } \\
\text { UMKM } \\
\text { meningkat dengan } \\
\text { adanya pelabuhan. }\end{array}$ & & $\begin{array}{l}\mathrm{K} \\
\mathrm{B}\end{array}$ & & & \\
\hline 4. & $\begin{array}{l}\text { Bagaimana } \\
\text { dampak } \\
\text { globalisasi, pasar } \\
\text { bebas dan } \\
\text { keterbukaan } \\
\text { ekonomi dunia } \\
\text { dengan adanya } \\
\text { pelabuhan. }\end{array}$ & $\begin{array}{l}\mathrm{S} \\
\mathrm{K} \\
\mathrm{B}\end{array}$ & & & & \\
\hline 5. & $\begin{array}{l}\text { Bagaimana } \\
\text { kondisi sosial, } \\
\text { politik dan } \\
\text { ekonomi pihak } \\
\text { pelabuhan dengan } \\
\text { masyarakat. }\end{array}$ & & $\begin{array}{l}\mathrm{K} \\
\mathrm{B}\end{array}$ & & & \\
\hline 6. & $\begin{array}{l}\text { Bagaimana bentuk } \\
\text { kerjasama antara } \\
\text { pihak pelabuhan } \\
\text { dengan } \\
\text { masyarakat. }\end{array}$ & & & & $\mathrm{B}$ & \\
\hline 7. & $\begin{array}{l}\text { Bagaimana } \\
\text { program } \\
\text { pemerintah dalam } \\
\text { mensejahterakan } \\
\text { masyarakat } \\
\text { dengan adanya }\end{array}$ & & & $\mathrm{N}$ & & \\
\hline
\end{tabular}




\begin{tabular}{|c|c|c|c|}
\hline & pelabuhan. & & \\
\hline 8. & $\begin{array}{l}\text { Apakah kerjasama } \\
\text { antar desa di } \\
\text { lingkungan } \\
\text { Kabupaten Gresik } \\
\text { semakin } \\
\text { meningkat dengan } \\
\text { adanya pelabuhan. }\end{array}$ & & B \\
\hline 9. & $\begin{array}{l}\text { Bagaimana } \\
\text { investasi } \\
\text { dilingkungan } \\
\text { masyarakat } \\
\text { dengan adanya } \\
\text { pelabuhan. }\end{array}$ & $\mathrm{N}$ & \\
\hline 10. & $\begin{array}{l}\text { Bagaimana } \\
\text { pengaruh } \\
\text { pembangunan } \\
\text { infrastruktur } \\
\text { pelabuhan } \\
\text { terhadap } \\
\text { pemanfaatan } \\
\text { potensi desa. }\end{array}$ & & B \\
\hline
\end{tabular}

Setelah melalui proses iterasi II, maka selanjutnya dalam proses Iterasi III adalah melakukan tanya-jawab kepada responden yang dianggap ahli yaitu Kepala Desa dari 3 kelurahan untuk mendapatkan persetujuan serta menyatukan persepsi para responden dalam menentukan faktor-faktor yang berpengaruh terhadap adanya pembangunan pelabuhan Pelindo III (JIIPE). Proses Iterasi III ini merupakan rangkuman dari seluruh pendapat/informasi yang dihasilkan dari para responden analisis SWOT. Kemudian, dimintakan persetujuan serta penentuan strategi mana yang harus digunakan dalam upaya peningkatan potensi Desa Mengare dengan adanya pembangunan pelabuhan Pelindo III (JIIPE) agar dapat menyusun konsep penanganannya sehingga prediksi awal tentang kejadian/peristiwa yang akan terjadi pada waktu ke depan akibat adanya pembangunan pelabuhan Pelindo III (JIIPE) ini dapat di tangani dengan suatu konsep penanganan yang benar dan tepat. Adapun faktor-faktor yang dihasilkan dari iterasi III dan disetujui berpengaruh meningkatkan potensi Desa Mengare terhadap adanya pembangunan pelabuhan Pelindo III (JIIPE) adalah:
1. Letak posisi geografis Desa Mengare yang dekat dengan pelabuhan menguntungkan untuk terbuka peluang kerja, pertumbuhan ekonomi dan distribusi barang/jasa.

2. Kualitas dan kuantitas masyarakat mampu untuk bersaing dalam perekrutan lapangan pekerjaan pelabuhan

3. Memanfaatkan sumber daya alam hasil desa dengan meningkatkan memberdayakan UMKM untuk di promosikan kepada pihak/tenagakerja pelabuha.

4. Meningkatkan kewirausahaan di sektor perekonomian mikro dan bekerjasama dengan desa dilingkungan Kabupaten Gresik dalam memasarkan produk.

5. Memanfaatkan sumber daya alam hasil laut untuk dijadikan produk usaha serta dipasarkan ke wilayah pelabuhan.

\section{KESIMPULAN}

Sehubungan dengan adanya pembangunan pelabuhan Pelindo III (JIIPE) Wilayah Gresik, pembangunan tersebut akan membawa dampak positif dan dampak negatif bagi masyarakat Desa Mengare. Oleh sebab itu, dampak positif dengan adanya pelabuhan dapat dimanfaatkan bagi warga desa, sedangkan dampak negatif adanya pelabuhan dapat diterima dengan cara menanggulangi dampak tersebut. Hasil identifikasi dengan menggunakan metode SWOT dan pendapat akhir metode Delphi menghasilkan alternatif strategi dengan nilai bobot paling tinggi 2,30 yaitu StrenghtOpportunity (SO) yang diartikan menggunakan kekuatan untuk memanfaatkan peluang dan kesempatan yang ada. Dampak positif dengan adanya pembangunan pelabuhan antara lain:

(1) Menunjang titik tumbuh perekonomian serta distribusi barang/jasa dalam rangka meningkatkan kesejahteraan masyarakat Desa Mengare.

(2) Perekrutan tenaga kerja pelabuhan dan masyarakat desa mempunyai peluang untuk menjadi tenaga kerja pelabuhan.

(3) Sumber daya hasil alam, hasil desa, hasil laut, dan pariwisata dapat di promosikan untuk menarik minat investor serta konsumen.

(4) Masyarakat akan meningkatkan kemampuan, partisipasi, dan pendidikan serta membuka berbagai macam usaha baru. 
(5) Masyarakat dapat mengirim Sumber Daya Alam hasil desa dari satu daerah ke daerah yang lain melalui pelabuhan.

Sedangkan dampak negatif dengan adanya pembangunan pelabuhan antara lain:

(1) Mempersempit lokasi nelayan dalam mencari ikan dan mengurangi potensi lahan yang dibuat menjadi tambak akibat reklamasi.

(2) Adanya globalisasi, pasar bebas dan keterbukaan ekonomi dunia serta timbul persaingan secara tidak sehat.

(3) Kemungkinan menambah tingkat pengangguran akibat peralihan profesi nelayan.

(4) Menambah tingkat abrasi pantai akibat ombak yang dibawah oleh kapal laut.

Berikut ini merupakan potensi Desa Mengare yang dapat dikelolah dengan adanya pembangunan pelabuhan:

(1) Pengolahan rajungan untuk diambil daging rajungannya saja dan dikemas sehingga konsumen tidak susah payah untuk mengupas cangkang rajungan lagi

(2) Pengolahan ikan bandeng menjadi bandeng tanpa duri (Batari), bandeng asap dan otakotak bandeng

(3) Pengolahan udang rebon untuk dijadikan terasi udang

(4) Pengelolahan ketela pohon yang dikupas kemudian dikeringkan terlebih dahulu dan diolah menjadi tepung tapioka

(5) Pengolahan jagung menjadi tepung jagung Adanya pembangunan pelabuhan tidak luput dari dampak posistif dan dampak negatif.
Dampak positif dengan adanya pembangunan pelabuhan harus dipertahankan, sedangkan dampak negatifnya harus diatasi. Misalnya, lokasi pencarian ikan nelayan pindah agak jauh dari lokasi sebelumnya, merekrut tenaga kerja dari Desa Mengare untuk mengurangi adanya pengangguran, dan membangun tanggul di dekat pantai untuk mengurangi abrasi air laut.

\section{REFERENSI}

Daryanto A. (2004). Keunggulan, Daya Saing dan Teknik Identifikasi Komoditas Unggulan dalam Mengembangkan Potensi Ekonomi Regional. AGRIMEDIA Volume 9 Nomor 2.MMA-IPB, Bogor.

Listyaningsih. (2014). Administrasi Pembangunan. Yogyakarta: Graha Ilmu.

Siagian, Sondang P. (2008). Administrasi Pembangunan: konsep, dimensi dan strateginya. Bumi Aksara: Jakarta.

Sjafari, Agus dan Sumaryo GS.(2012). Pembangunan Masyarakat (Teori dan Implementasi di Era Otonomi Daerah). Serang: FISIP Unitra Press,.

Todaro, P. Michael and Smith, C. Stephen. (2006). Economic Development $9^{\text {th }}$ Edition (terj). Jakarta: Erlangga,.

Worosuprodjo S.(2007). Pengelolaan Sumberdaya Lahan Berbasis Spasial dalam Pembangunan Berkelanjutan di Indonesia. Pidato pengukuhan jabatan Guru Besar pada Fakultas Geografi UGM, Yogyakarta. 